\title{
First record of Porocephalus cf. clavatus (Pentastomida: Porocephalida) as a parasite on Bothrops asper (Squamata: Viperidae) in Costa Rica
}

\author{
G. Alvarado ${ }^{a, b, c *}$ and A. Sánchez-Monge $e^{a, b, d, e}$ \\ ${ }^{a}$ Centro de Investigación en Estructuras Microscópicas - CIEMIC, Universidad de Costa Rica - UCR, 2060, \\ San Pedro de Montes de Oca, Costa Rica

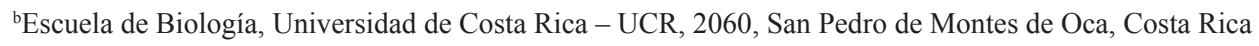 \\ 'Departamento de Patología, Escuela de Medicina Veterinaria, Universidad Nacional de Costa Rica - UNA, \\ 86-3000, Heredia, Costa Rica
}

${ }^{d}$ Escuela de Estudios Generales, Universidad de Costa Rica - UCR, 2060, San Pedro de Montes de Oca, Costa Rica

'Nematology Research Unit, Department of Biology, Ghent University - UGent, Ledeganckstraat, Ghent, Belgium

*e-mail: gilbert.alvarado@ucr.ac.cr

Received: January 17, 2014 - Accepted: April 28, 2014 - Distributed: November 30, 2015

(With 2 figures)

\begin{abstract}
Pentastomids are parasites that infect respiratory cavities of vertebrates, they are pretty common but poorly known in wildlife veterinary. A Bothrops asper snake (Garman, 1884) was captured in the Caribbean region of Costa Rica and had its lung infested with pentastomids, identified as ca Porocephalus clavatus (Wyman, 1845). This represents the first record of Porocephalus (Humboldt, 1812) on B. asper as well as P. cf. clavatus in Costa Rica. Further studies are needed to clarify their taxonomic position, images and scanning electron microscopy photographs (SEM) of the specimens are given.
\end{abstract}

Keywords: parasite, pentastomiasis, Bothrops asper, snake, neotropic.

\section{Primeiro registro de Porocephalus cf. clavatus (Pentastomida: Porocephalida) como um parasita em Bothrops asper (Squamata: Viperidae) na Costa Rica}

\section{Resumo}

Pentastomídeos sâo parasitas que infectam as cavidades respiratórias dos vertebrados, eles são bastante comuns, mas pouco conhecido nos animais silvestres. Uma Bothrops asper (Garman, 1884) foi capturada na região do Caribe da Costa Rica e teve seu pulmão infestado de pentastomídeos, identificados como ca Porocephalus clavatus (Wyman, 1845). Isto representa o primeiro registro de Porocephalus (Humboldt, 1812) em B. asper, assim como P. cf. clavatus na Costa Rica. Mais estudos detalhados são necessários para esclarecer sua posição taxonómica. Imagens e fotografias de microscopia electrónica de varredura (MEV) dos espécimes são dadas.

Palavras-chave: parasita, pentastomiasis, Bothrops asper, serpente, neotrópico.

\section{Introduction}

Pentastomids are parasites in the respiratory tract of vertebrates (Almeida et al., 2007, 2008a) with 144 recent species, particularly common in reptiles (Christoffersen and Assis, 2013; Riley, 1986). The pentastomiasis is well known in animals that come from the captivity but little information is available on wild animals. This group is neglected both in the books and in the curriculum of veterinary medicine, those veterinarians who practice herpetological medicine have a higher probability to find these wormlike organisms. The pentastomes of reptiles have zoonotic potential, but among these parasites only Armillifer, Raillietiella, and
Porocephalus have been associated with human infections (Riley, 1986; Qiu et al., 2005; Meyers and Neafie, 2011).

The genus Porocephalus comprises nine species that infect lungs of snakes in America and Africa (Christoffersen and Assis, 2013; Gomez-Puerta et al., 2011; Poore, 2012). This genus is recognized by females' head swollen but without a neck, annuli obvious in nymphs but not in adults, oval or keyshaped mouth in the line of the inner hooks and by internal hooks simple and external hooks double in both, nymphs and adults (Riley and Self, 1979). This spinous extension over the external hook (so called 
double hook) is the only consistent character for this genus (Riley and Walters, 1980).

Porocephalus has been reported from at least a dozen species and subspecies of snake hosts ranging from North to South America where they could be found occasionally in intermediate hosts such as dogs (Brookins et al., 2009), primates (Pereira et al., 2010), opossums, rodents and other mammals (Christoffersen and Assis, 2013; Poore, 2012). The knowledge on Central American species and diversity remains mostly unknown. In this paper we inform for the first time the presence of Porocephalus cf. clavatus, in the lungs of a Bothrops asper (wild female specimen). Images and descriptions of the affected tissues and the pentastomids recovered are given.

\section{Material and Methods}

A Bothrops asper female was collected in Siquirres, Limón (28/III/2011) in the Caribbean region of Costa Rica and translated to the Department of Pathology at the Escuela de Medicina Veterinaria, Universidad Nacional (UNA). The animal presented low weight, severe dehydration, slow movements and an alike nodular lesion on the left eye. Euthanasia was performed immediately by Randall Arguedas and Gilbert Alvarado (both wildlife veterinarians), euthanasia solution was administrated via cardiac puncture and animal was previously anesthetized.
Necropsy revealed the presence of pentastomids in the lung and the gastrointestinal cavities, specimens were isolated and stored in $70 \%$ ethanol.

Identification of the pentastomids was made according to Vargas (1970) and Riley and Self(1979). Specimens' features were examined under a Nikon SM2800 stereomicroscope at the UNA and photographed with a Pentax Optio WG1 digital camera. Scanning electron images were obtained with a Hitachi S3700N scanning electron microscope in variable pressure mode at the Microscopic Structures Research Center (CIEMIC), University of Costa Rica (UCR). Annuli of all specimens recovered (but two males in bad conditions) were estimated directly at the UNA, length measures were obtained from photographs with the program UTHSCSA Image Tool for Windows Version 3.00. Data on immatures are not presented.

\section{Results}

Six females and 13 males were extracted from the snake examined. The number of annuli in females and males ranged between 34-36 and 39-45 respectively (Table 1), bodysize was estimated in $67.54 \pm 6.63 \mathrm{~mm}$ for females $(\mathrm{N}=6)$ and $20.39 \pm 2.38 \mathrm{~mm}$ for males $(\mathrm{N}=13)$. Most of them were found in the lung cavity (Figure 1), only one male was isolated from visceral cavities.
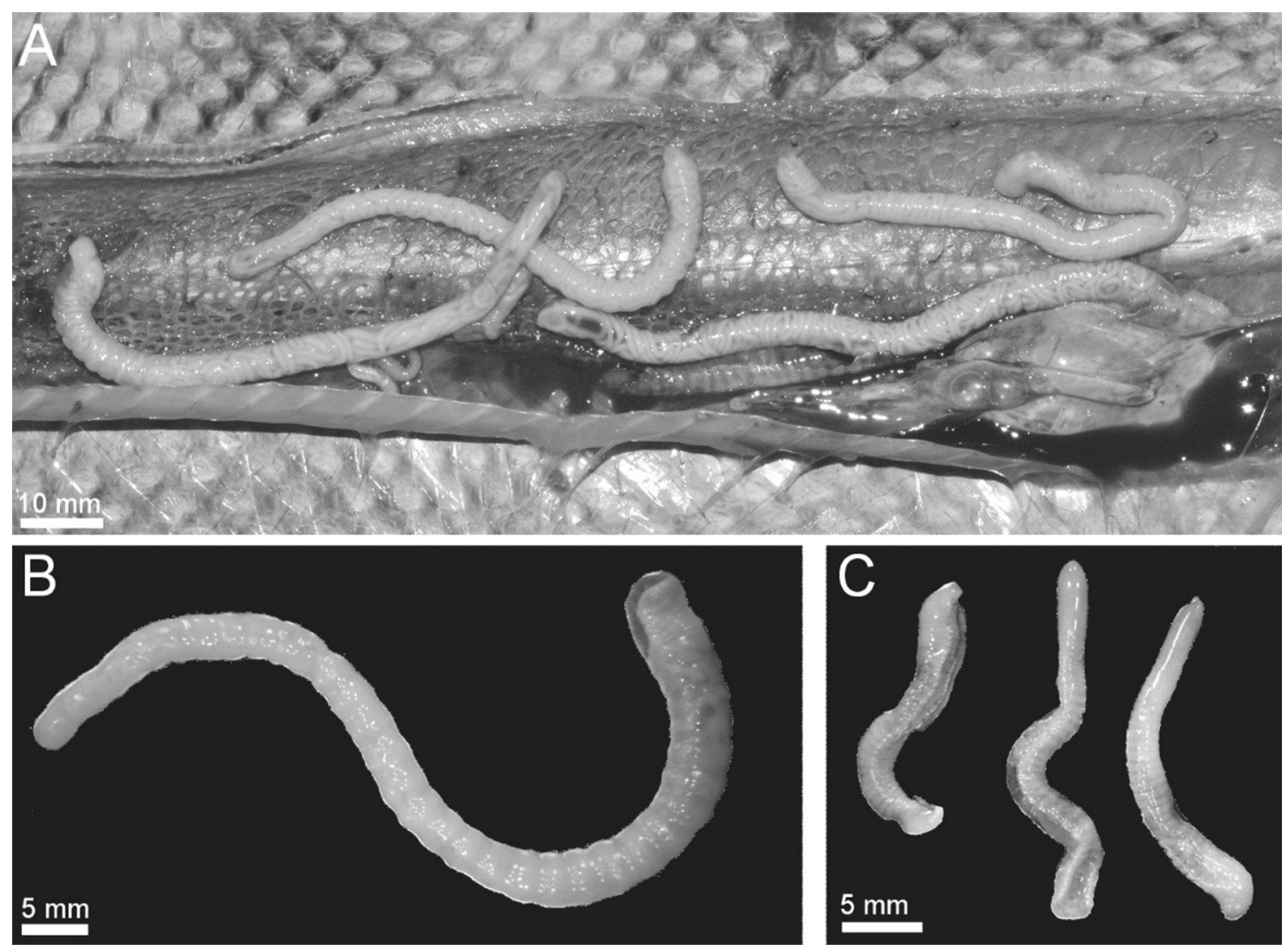

Figure 1. Porocephalus sp. found in lung cavity of Bothrops asper, Costa Rica. (A) Infection during isolation (B) Female and (C) Males. 


\section{Discussion}

\subsection{Taxonomic status}

According to Riley and Self (1979), the specimens found belong to $P$. clavatus based on the number of annuli and previous reports, however, the sizes in Table 1 for females exceed the ranges established for this species. Pentastomids found by those authors in Bothrops had the same number of annuli and the same hooks to those of $P$. clavatus but as the case of the specimens reported herein, the females size was much larger.

We agree with Riley and Self that this is probably a new species but just size is not enough support for segregation (Riley and Self, 1979) since it could be influenced by hosts and age (Vargas, 1970). Hook parameters could be key information for species segregation (Riley and Self(1979) but in this case such data could not be determined because the low number of specimens collected (see Figure 2 for hooks photographs).

This is the first report of Porocephalus ex Bothrops in the asper species and of this $c f$. P. clavatus for Costa Rica. Regrettably, information on collection sites and host species are not accurate in all sources and the so-called "SouthAmerica" could be referring to the lands at the south of the United States of America, maybe including Central and SouthAmerica sensu stricto. In the latter region, Brazilian snakes are common host for pentastomids
(Almeida et al., 2006, 2007, 2008b, c; Ávila et al., 2013; Brito et al., 2012) and since some of these snake's species are distributed in northern areas (Central America i.e.) future records of Pentastomids might be possible if sampling and searching increase. Further studies on this taxa ex Bothrops asper should be addressed with a greater number of specimens and hosts to clearly define its taxonomic position.

Table 1. Annuli number of females and males of Porocephalus sp. ex Bothrops asper, Costa Rica.

\begin{tabular}{ccc}
\hline Specimen & Females & Males \\
\hline 1 & 34 & 39 \\
2 & 35 & 40 \\
3 & 36 & 40 \\
4 & 36 & 40 \\
5 & 36 & 41 \\
6 & 36 & 41 \\
7 & --- & 41 \\
8 & --- & 42 \\
9 & --- & 42 \\
10 & --- & 43 \\
11 & --- & 45 \\
Media & 35.50 & 41.27 \\
SD* & 0.84 & 1.68 \\
\hline
\end{tabular}

*Standart Deviation.
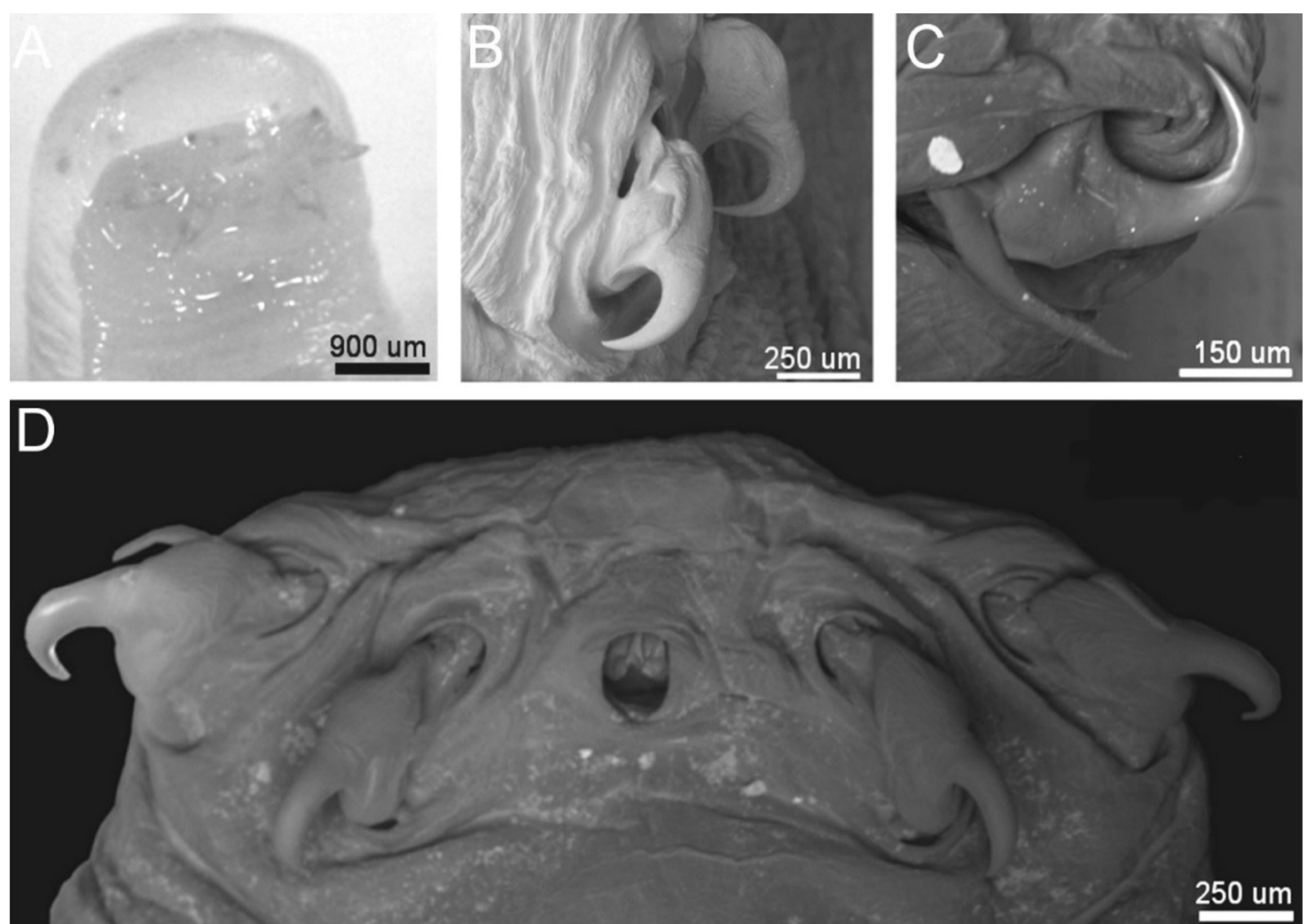

Figure 2. Porocephalus sp. ex Bothrops asper, Costa Rica. (A) Cephalothorax under stereomicroscope. (B). Female hooks, dorsal view. (C) Male external hook dorsal view and (D) Female anterior ventral view under SEM. 


\section{Conclusion}

Even though pentastomes are not well known in wild life veterinary, they could be very common to find in snakes and other reptiles. Further surveys are necessary to clarify the species definition within the genus Porocephalus and increase the knowledge on the diversity of this group in tropics. The pentastomids found in this case are the first report ex Bothrops asper and could belong to a new species.

\section{Acknowledgements}

We thank the support of the CIEMIC and the project FEES-CONARE (810-B2-658) for microscope analysis. We appreciate the literature provided by Luis Gomez-Puerta and Mario Vargas Vargas. We thank Edwin Gómez for collecting the animal in field, Juan Alberto Morales and the Department of Pathology of the Escuela de Medicina Veterinaria, Universidad Nacional for helping with the necropsy and to Randall Arguedas for collaborating with euthanasia. We specially thank Alexander Rodriguez who arranged the visit of Luis Gomez Prieto (UNAM) through the project "Simplificando el acceso al estudio de la biodiversidad costarricense, Costa Rica como un centro de investigación internacional en medio ambiente y biodiversidad" (from the Mexican Program of International Cooperation for Development), visit that awoke the interest in the study of the specimens. Lastly, we highly appreciate the comments and suggestions from the anonymous reviewers whose constructive observations increased the quality of the paper.

\section{References}

ALMEIDA, W.O., BRITO, S.V., FERREIRA, F.S. and CHRISTOFFERSEN, M.L., 2006. First record of Cephalobaena tetrapoda (Pentastomida: Cephalobaenidae) as a parasite on Liophis lineatus (Ophidia: Colubridae) in northeast Brazil. Brazilian Journal of Biology $=$ Revista Brasileira de Biologia, vol. 66, no. 2A, pp. 559-564. http://dx.doi.org/10.1590/S151969842006000300023. PMid:16862312.

ALMEIDA, W.O., VASCONCELLOS, A., LOPES, S.G. and FREIRE, E.M.X., 2007. Prevalence and intensity of pentastomid infection in two species of snakes from northeastern Brazil. Brazilian Journal of Biology $=$ Revista Brasileira de Biologia, vol. 67, no. 4, pp. 759-763. http://dx.doi.org/10.1590/S151969842007000400025. PMid:18278332.

ALMEIDA, W.O., CHRISTOFFERSEN, M.L., AMORIM, D.S. and ELOY, E.C., 2008a. Morphological support for the phylogenetic positioning of the Pentastomida and related fossils. Biotemas, vol. 21, no. 3, pp. 81-90. http://dx.doi. org/10.5007/2175-7925.2008v21n3p81.

ALMEIDA, W.O., GUEDES, T.B., FREIRE, E.M. and VASCONCELLOS, A., 2008b. Pentastomid infection in Philodryas nattereri (Steindachner, 1870) and Oxybelis aeneus (Wagler, 1824) (Squamata: Colubridae) in a caatinga of Northeastern Brazil. Brazilian Journal of Biology $=$ Revista Brasileira de Biologia, vol. 68, no. 1, pp. 193-197. http://dx.doi.org/10.1590/ S1519-69842008000100028. PMid:18470397.
ALMEIDA, W.O., FERREIRA, F., GUARNIERI, M. and BRITO, S., 2008c. Porocephalus species (Pentastomida) infecting Boa constrictor (Boidae) and Lachesis muta (Viperidae) in northeastern Brazil. Biotemas, vol. 21, no. 2, pp. 165-168. http://dx.doi. org/10.5007/2175-7925.2008v21n2p165.

ÁVILA, R.W., MORAIS, D.H., ANJOS, L.A., ALMEIDA, W.O. and SILVA, R.J., 2013. Endoparasites infecting the semiaquatic coral snake Micrurus surinamensis (Squamata: Elapidae) in the southern amazonian region, Mato Grosso state, Brazil. Brazilian Journal of Biology $=$ Revista Brasileira de Biologia, vol. 73, no. 3, pp. 645-647. http://dx.doi.org/10.1590/S151969842013000300024 . PMid:24212707.

BRITO, S.V., ALMEIDA, W.O., ANJOS, L.A. and SILVA, R.J., 2012. New host records of Brazilian pentastomid species. Brazilian Journal of Biology = Revista Brasileira de Biologia, vol. 72, no. 2, pp. 393-396. http://dx.doi.org/10.1590/S151969842012000200022. PMid:22735149.

BROOKINS, M.D., WELLEHAN, J.F.X., ROBERTS, J.F., ALLISON, K., CURRAN, S.S., CHILDRESS, A.L. and GREINER, E.C., 2009. Massive visceral Pentastomiasis caused by Porocephalus crotali in a dog. Veterinary Pathology, vol. 46, no. 3, pp. 460-463. http://dx.doi.org/10.1354/vp.07-VP-0246R-BC. PMid:19176495.

CHRISTOFFERSEN, M.L. and ASSIS, J.E., 2013. A taxonomic monograph of the recent Pentastomida, with a compilation of their hosts. Zoölogische Mededeelingen, vol. 87, no. 1, pp. 1-206.

GOMEZ-PUERTA, L.A., LOPEZ-URBINA, M.T. and GONZALEZ, A.E., 2011. Presence of Porocephalus clavatus (Arthropoda: Porocephalidae) in Peruvian Boidae snakes. Veterinary Parasitology, vol. 181, no. 2-4, pp. 379-381. http:// dx.doi.org/10.1016/j.vetpar.2011.04.005. PMid:21531511.

MEYERS, W.M. and NEAFIE, R.C., 2011 [viewed 15 December 2013]. Pentastomiasis [online]. Washington: Armed Forces Institute of Pathology of Tropical and Extraordinary Diseases. Available from: http://www.dtic.mil/get-tr-doc/pdf?AD=ADA547699

PEREIRA, W.L.A., BENIGNO, R.N. and SILVA, K.S., 2010. Fatal infections in a captive Pithecia irrorata (primate) by Porocephalus sp. (Pentastomida). Veterinary Parasitology, vol. 173, no. 3-4, pp. 358-361. http://dx.doi.org/10.1016/j. vetpar.2010.07.010. PMid:20850934.

POORE, G.C., 2012. The nomenclature of the recent Pentastomida (Crustacea), with a list of species and available names. Systematic Parasitology, vol. 82, no. 3, pp. 211-240. http://dx.doi.org/10.1007/ s11230-012-9363-x. PMid:22711510.

QIU, M.H., MA, K.C., FAN, P.C. and LU, S.S., 2005. Discovery of a new species of the pentastomid genus Porocephalus (Humboldt, 1811) from Taiwan, China and its pathogenic features. Zhongguo Ji Sheng Chong Xue Yu Ji Sheng Chong Bing Za Zhi= Chinese Journal of Parasitology \& Parasitic Diseases, vol. 23, no. 2, pp. 69-72. PMid:16042166.

RILEY, J. and SELF, J., 1979. On the systematics of the Pentastomid genus Porocephalus (Humbolt, 1811) with descriptions of two new species. Systematic Parasitology, vol. 1, no. 1, pp. 25-42. http://dx.doi.org/10.1007/BF00009772.

RILEY, J. and WALTERS, L., 1980. Porocephalus dominicana n. sp. from the dominican boa (Constrictor constrictor nebulosus). 
Systematic Parasitology, vol. 1, no. 2, pp. 123-126. http://dx.doi. org/10.1007/BF00009858.

RILEY, J., 1986. The biology of pentastomids. Advances in Parasitology, vol. 25, pp. 45-128. http://dx.doi.org/10.1016/ S0065-308X(08)60342-5. PMid:3535437.
VARGAS, M., 1970. A contribution to the morphology of the eggs and nymphal stages of Porocephalus stilesi (Sambon, 1910) and Porocephalus clavatus (Wyman, 1847) Sambon, 1910 (Pentastomida). Revista de Biologia Tropical, vol. 17, no. 1 , pp. 27-89. 